\title{
GENERAL PROVISIONS OF THE DOCTRINE OF OBLIGATION
}

\section{Golubeva N. Yu.}

\section{INTRODUCTION}

The problem of developing the theoretical foundations for the regulation of civil relations has always stood in front of civil scientists. Particular attention is paid to this problem in nowaday's context. Civil legislation must address the main task - to ensure the dynamic and progressive development of the economy on market, competitive principles.

The Civil Code of Ukraine in 2003 (hereinafter referred to as "the CC") substantially changed the rules of the general part of the law of obligations compared to the $\mathrm{CC}$ of 1963. As this normative act incorporates the achievements of national and world theory and practice of civil law, therefore, their correct perception and use is impossible without a comprehensive and complete study of both historical and modern experience of applying the relevant norms, analysis of the need for improvement of legislation. According to V.I. Golevinsky, building a correct theory on obligations is one of the most important tasks of science and one of the most vital issues for any evolving legislation ${ }^{1}$.

Renewed civil law requires a rethinking of many theoretical problems of civil law, including the need to understand and establish the possibility of using constructions of foreign legal systems ${ }^{2}$.

Today it is relevant to formulate basic provisions on obligations on a single methodological basis, to create a scientific concept, since only having a common theory, doctrine, concept, we can speak about the improvement of legislation on obligations. The Legislation on obligations is so wide that its creation on various methodological and conceptual principles poses a threat to the successful development of the economy, and therefore to the development of the country as a whole.

The need to build a general theory on obligations (in law - a common part of the obligation law) is indisputable. Only after establishing general provisions it is possible to successfully anticipate and identify separate, most

\footnotetext{
${ }^{1}$ Голевинский В.И. О происхождении и деленииобязательств. Варшава: Тип. О. Бергера, 1872. С. 25.

2 Докладно методологія побудови вчення зобов'язання була окремо досліджена у наступній праці: Голубєва Н.Ю. Зобов’язання у цивільному праві України : методологічні засади правового регулювання : монографія. Одеса: Фенікс, 2013. 642 с.
} 
commonly encountered, relations on obligations. However, the historical development of law and science went the other way - separate obligations were formulated in law and doctrine earlier than general theory. But only the development of a general theory on obligations in the legislative order, the establishment of abstract bases of the obligation law, allowed to depart from legal formalism, casuistry, the regulation of specific relationships to effectively regulate new obligations that appear with the development of society.

General obligations are the principles that must be met by any obligation, unless otherwise specified in the law, the contract, their development is a difficult task of the legislator (first of all, it is a task, of course, of the doctrine, but the point is still set by the legislator).

The doctrine on obligation, as the doctrine of the basic principles on obligation, rather than the doctrine of particular cases on obligations, is becoming methodologically relevant today and is the starting point for further research.

\section{Obligatory law as a branch of civil law}

The category of obligations is one of the key concepts in the system of civil law concepts and categories that existed in the most ancient legislation.

In early Roman civil law, it was not yet about "obligations" but about ways of acquiring things and protecting the rights that arose in the course of committing these actions (actio). Only in the times of classical Roman private law the notion of obligation was formed (obligatio), a feature of which is: the universality of the formulation of obligations for different types of obligations; obligation to perform; addressing the person, not things.

Despite many common features of the modern conception of obligations and ancient Roman law, Roman law is characterized by several features that have been significantly deformed in modern law and order. First, even at the highest stage of development, Roman law has not come to the recognition that any legal agreement between the two parties to establish any obligation has itself legal force ${ }^{3}$. Second, the obligation was a purely personal relationship between two or more individuals. This principle was reflected in the following provisions: as a rule, it was impossible to enter into obligations through a representative; no contracts were recognized for the benefit of a third party; as a rule, the possibility of replacing the parties in the obligation was not recognized. Third, Roman law provided for a strictly limited list of obligation forms strictly related to its special claim: where there were no claims, there

3 Харитонов Е. Категория обязательств в римском частном праве. Юридический вестник. 1997. № 1. С. 105. 
were no obligations, and vice versa. Fourth, Roman law was characterized by the extreme severity of the debt burden. Initially, there was a possibility of recovering the debt on the individual of the debtor. Much later, the penalty was transferred to his/hers property.

However, the system of obligations of Roman law was so successful that it was later borrowed by the vast majority of European states. This does not mean that obligation law is fully reciprocated by later legal systems, but the impact is undeniable. The level of integration of European countries is largely due to the reception of Roman law.

The genesis of obligation law in Ukraine has peculiar features and dates back to the pre-state period, when it was first regulated by mono-norms and then by customary norms. The development of binding standards was also characteristic of the Scythian state, the ancient cities-states located in the territory of modern Ukraine. The emergence and development of Kievan Rus and its main inheritance, the Russkaya Pravda, had great importance for the further development of the obligation law in Ukraine. This period of development of the law of obligations is characterized by the improvement of various contractual forms, rules on compensation for the damage caused. As in Roman law, the severe consequences of breach of obligations and damage were foreseen. The charge was applied to the debtor.

In the period of feudal fragmentation of Russia, the obligation law remained in the same state as in the previous period, which was due to the fact that the leading legal act remained the "Russkaya Pravda".

According to the Lithuanian statutes, a rather comprehensive system of norms, in comparison with others, had providing institutions: a bail, a deposit, a guarantee, a pledge. In general, the mandatory rules in these regulations were rather limited and small. Instead, compulsory law was the main legal institution of civil law of the Hetmanate. The contractual obligations and obligations on compensation of damage were thoroughly regulated.

Analyzing the legislative acts, which were in force in one or another way in the Ukrainian lands, we find that the legislation paid little attention to the general provisions on obligations and the contract. Most of the rules are dedicated to specific types of contracts.

In the second half of the XVIII century the legislation of the Russian Empire is being extended in Ukraine. Along with the Code of Civil Law, common in all areas of the Russian Empire, there was also national-regional civil law.

In the Soviet period, the development and emergence of new institutes of the obligation law was conditioned by the adoption of the Civil Code of the Ukrainian SSR in 1922. The institutes of the law of obligations were enshrined in a separate section, and the law of that period had elements of the 
imperative method of regulation. More dispositive was the $\mathrm{CC}$ of the Ukrainian SSR in 1963.

Contemporary compulsory law of Ukraine is recognized as a branch of civil law, primarily because it regulates relatively homogeneous contractual and non-contractual obligations, contains rules of general and special action, which have a substantive and functional orientation.

The norms of compulsory law first and foremost regulate property relations related to the exchange of results of activities of participants of civil turnover (which includes economic turnover, as well as the turnover of nonproperty benefits).

As a set of civil law regulations governing civil turnover, the law of obligations constitutes a certain system of civil law rules and is divided into General and Special parts.

Section 2 of the Book. 5 of the CC "General provisions of the contract" is separated into a separate block outside the general provisions on obligations, but not to be construed as an independent group of rules, relative to the system of rules of obligations.

The importance of the obligation law for the development of society is manifested in the following functions: first, the rules of the obligation law are intended to strengthen the legal protection of the interests of conscientious participants of the civil turnover; second, the consolidation and legal regulation of the relations of the civil turnover, ensuring their organization, order and stability, promoting their further strengthening and development (economic commitment function); thirdly, the promotion of the achievement exactly those goals of which the links between the subjects of civil trafficking are intended.

The main tendencies in the development of the obligation law are: unity, differentiation and unification of special legislation, prevailing development of contract law, differentiation of contract law by economic activity, strengthening globalization.

\section{The concepts and main characteristics of obligation}

The recognition of the essence of any legal phenomenon involves, first of all, an investigation of its nature. According to modern interpretation in Ukrainian civil science, the concept and essence of obligations are one of the types of civil legal relations.

The term "obligation" cannot be equated with the term "duty". The relevance of the issue of the relationship and the delimitation of the obligation from the duty is due to the existing confusion in the current law enforcement practice and the inaccuracy in the delimitation of the obligation from the public legal duty. 
Obligation is a civil legal relationship, a structural element of the content of which is the debtor's duty, but the notion of duty is universal and not always part of the obligation.

Obligation legal relations differ from property legal relationships: 1) by the number of related persons (in the obligation it is only the creditor and the debtor, and this is known, specifically identified persons at the time of the emergence of relationship); 2) by the object (in the obligation it is not a thing, but the action of the obliged person, and in the obligation the object may not be clearly defined (eg, determined genetically, alternatively, etc.); 3 ) on the grounds of occurrence (except that these grounds differ significantly, the fundamental point is that the obligation may arise as a result of both lawful and unlawful acts, and the legal property relations do not arise as a result of the offenses); 4) by the specific form in which the rights and obligations are expressed (obligation is a claim and a debt); 5 ) in substantive legal relations the essence of subjective right is reduced to the right to one's own behavior; in relative legal relations it becomes the right to demand specific behavior from the obliged persons. 6) by the nature of the realization (in the obligation, the creditor's right can be exercised only in the performance of the debtor's obligations, and not by committing by authorized person his/hers own actions on a particular, except for the features contained in Art. 621 of the Civil Code of Ukraine); 7) according to the peculiarities of legal regulation (not only the regulation of the origin, protection and termination of the right is important for the obligation, but also the clearly defined procedure for fulfilling the obligation); 8) by value for civil turnover (the obligation reflects the dynamics of civil rights and obligations, that is, the obligation observes the civil turnover, and the property legal relations fix the statics, the ownership of property rights outside the exchange between the participants of the civil turnover); 9) at the time of existence (the obligation of the relationship is always temporary: concluded for a known time or with an indefinite duration of the obligation, limited by the actual interest of the creditor in the performance); 10) common to the various obligations is the need for interaction between the parties to the obligation, both contractual and non-contractual, in order for it to be fulfilled; in order for it to be enforced, however, such interaction is not peculiar to property law; 11) the circle of obligations is not defined in the law, the types of obligations are incomparably bigger than property rights; 12) property relationships are always material, and obligatory, though rare, but not always.

But, despite the differences in these types of relationships, they are interconnected and interdependent. The Civil Code also partly considers it possible to apply remedies to obligations (Art. 621 of the CC). 
The specificity of the obligation as a civil legal relationship are as follows: 1) the obligations basically mediate the process of moving tangible and intangible goods; 2) the obligatory legal relations are always established with a specific subject and, therefore, have a relative nature; 3) obligations generally contain an obligation to take certain active actions, but may also include passive actions, in some cases, include only passive actions; 4) obligations do not create duty for persons who do not participate in it as parties. However, the obligation may give rise to rights for the third party against the debtor and (or) the creditor (Art. 636 of the CC); 5) the object of the obligation is a certain behavior of the debtor, the object of the obligation are those things or property, intangible goods in respect of which there is interest of the participants of this legal relationship; 6) the specificity of the content of the subjective obligation law is that it is always a right not to one's own, but to another's (debtor's) actions, reduced not to the permissibility of one's own actions by the authorized person, but to ensuring the possibility of performing these actions; 7) obligations have a special meaning (right to claim and debt); 8) is established, as a rule, for a definite period, that is, on the basis of a further termination; 9) the application of special methods of coercion to the offender in the case of non-performance and improper performance of the obligation, that is, in breach of the obligation.

The object of the obligation is the action of the debtor. An action is that external object to which the right is directed, which in turn is realized in relations.

Thus, the object of the obligation is thaton what the rights and obligations that make up the content of the obligation are directed, that is, those actions which (or withholding from which) the creditor is entitled to demand from the debtor; the subject of obligation are those tangible and intangible goods to which the parties enter into relations and to which their actions are directed. For example, a liability arising from a purchase and sale agreement involves the transfer of property and the payment of that property, and the subject matter is the specific property for which the purchase and sale agreement is concluded. In some obligations, the item is generally absent, for example, in some contractual obligations to provide services.

In this case, the object and the content of the obligation do not coincide, since the object is the actions (behavior, including withholding of actions) of the debtor, and the content is the obligation - the debtor's debt and the right of the creditor to claim. Benefits, on which is directed the execution have diverse character depending on the type of commitment. In the obligations arising from property transfer agreements, the object of performance is the property, in the obligation to perform the work - the result of the work, in the obligation to provide services - the service itself as a special type of activity. The object 
of performance in non-contractual obligations, as well as in obligations arising from contracts for the transfer of property, is property (for example, in the obligation to compensate for damage it has the nature of compensation for the damage caused, in the obligations negatorim gestio - compensation of cost, etc.).

Actions as an object of obligation can be active (positive) and passive (negative). All kinds of activities can be reduced to two. The first of these: "give" is an action that aims to make a change in substantive law (transfer of thing to property, temporary use, etc.), to increase the property of the creditor in another way (cession, debt relief).

A group of obligation, the object of which is to "transfer", can be divided into subgroups, depending on the specific subject of the transfer, the purpose of the transfer and the result (legal title acquired by the person who took over the property).

First, the obligation may be directed to the transfer by the party into the property of the other party of anything, individually determined or defined by generic characteristics, in particular, to pay a certain amount of money (sale, mine, gift, life-support, rent), as well as the transfer of rights (for example, claim rights).

Second, the obligation may be directed to the transfer by the party to the other party of any other substantive right (an agreement establishing an easement).

Third, the obligation may be directed to the provision by the party for the use of the other party of the thing, with the transfer of the individually determined thing on condition of return of the thing to the owner (rent (lease), loan (free use of property), as well as rent of housing).

Fourth, the obligation may be directed to other types of "transfer": 1) the issuance of a remuneration (in the obligations arising from a public promise of a remuneration without announcing a competition); 2) the issuance of award (in the obligations arising from the public promise of the award as a result of the competition); 3 ) compensation of expenses (in the obligations arising from committing actions in the property interests of another person without his/her assignment); 4) compensation for the damage caused, (in the obligation in case of creation a threat to the life, health and property of an individual or property of a legal entity; obligations arising from causing harm); 5) compensation for the value of acquired or preserved property without sufficient legal basis.

Actually, the fourth group may be in some way attached to the first (after all, it is ultimately the transfer, in most cases, of money or things to the other party), but due to the specifics of the rules on non-contractual obligations, it stands out separately. 
Fifth, the obligation may be directed at returning the property to its owner in the obligations arising out of the acquisition or retention of the property without sufficient legal basis.

The second group of active actions: "do something" covers the whole range of actions not covered by the term "give". The most important of these actions are those covered by the word "work", which is understood in the classical literature quite widely, and today, traditionally, is divided into two groups of actions: the actual work in the narrow sense of the word (performed in the framework of contractual obligations type) and services.

The action that constitutes the object of the obligation may also be negative. Depending on the purpose, the following restraints may be distinguished from the object of the obligation. The action that constitutes the object of the obligation may also be negative. Depending on the purpose, it may be distinguished the following withholding acts from action as the object of the obligation: 1) aimed at making things more efficient and easier to use; 2) aimed at creating the possibility of using the thing; 3) are aimed at withholding the use of the thing or the use of this property in own interest (the carrier and the custodian are not entitled to use the property transferred to them for performance of the contract); 4) aimed at building effective competitive relations (abstaining from competition, abstaining from entering into a commission agreement with other persons). This list is not closed, because it depends on the interests of the creditor, the limit of which should be the inadmissibility of limiting the capacity of persons.

Analyzing the possible varieties of the object of obligation, it can be distinguished obligations: 1) those whose object is the transfer of property; 2) those whose object is to perform the work; 3 ) those whose object is to provide services; 4) those whose object is to refrain from action. Of course this is not taken into account various combinations of actions in a single obligation.

Actions can be both one-off, multiple, and lasting. A one-time action (or a one-time satisfaction when considering this from an obligation standpoint) should be understood as an action (s), which is carried out in one moment. Repeated acts of a debtor may have multiple (the execution of the debtor may be embodied in several active transactions, in a series of identical acts of execution over a period of time) or continuous nature over a period of time.

An obligation (a certain behavior of obliged person) may be divisible and indivisible.

An object is divisible when an action can be taken in parts, such as paying money. Thus the object (action) is divided without disturbing the essence, so that each part of the action has the same meaning as the whole, and differs from the latter only quantitatively. The indivisibility of an object of obligation (action) comes: 1) by virtue of the indivisibility of the object of performance (the thing to which the action is directed), without changing the property and 
reducing its value; 2) by virtue of the indivisibility of the action itself, that is, the impossibility of performing it in parts at all, for example, the making of a sculpture or the performance in negative obligations; 3 ) if the object (action) is separate in itself, but its implementation in parts does not satisfy the interest of the creditor; 4) by virtue of the agreement the action, which is itself divisive, is recognized as indivisible, for example, the construction of a house.

As a general rule, the obligation is indivisible, the debtor is not entitled to transfer in part the subject of the obligation (Art. 529 of the CC).

The extent of defining the object of the obligation may be different: 1) the object is specifically (absolutely, precisely) defined as unique or individualized actions; 2) the object is defined only by genus, generically (not by species), by determining the amount, weight, volume of the thing that constitutes the transfer; at the stage of fulfillment, such an obligation will inevitably be transformed into types (the right to determine specific, individualized property for transfer to the buyer belongs to the seller, since it is he/she who distinguishes from the mass of similar goods those that will be transferred to the buyer); 3) the amount of debt of the debtor can be established only in general form (obligation with an indefinite amount of claims - aleatory), but the obligation sets the criteria for determining specific amounts and services at the stage of performance of the obligation; 4) the object is identified as an alternative obligation.

Obligations may be emerge relatively several objects (binding, alternative and optional obligations). Obligations with a simple multiplicity of an object (binding commitments) are distinguished by the fact that the object of it is several actions that the debtor must perform in full without the right to choose one or another action, the debtor must perform all actions.

An object of obligation may be several separate actions, of which only one must be performed, at the option of one of the parties of the obligation alternative obligations. However, these actions are defined. Uncertainty lies the unknown of what the action will accomplish. One of several actions must be performed, so it will not be considered proper to fulfill each obligation in part. It is proposed to supplement Art. 539 of the Civil Code of Ukraine part 2 of the following content: "the party of the obligation, which has the right to choose the subject of performance in the alternative obligation, cannot compel the other party to perform or accept part of or part of the other performance object".

The most important question in an alternative obligation is to determine the person who has the right to choose the object of performance. The right to choice usually belongs to the debtor. By virtue of the law or the agreement of the parties, the right to choice may belong to the creditor (for example, under Art. 8 of Law of Ukraine "On Consumer Protection") or a third party. In some cases, the CC gives the right to choose (Art. 1192). 
Alternative plurality is characterized by the need to choose between mutually exclusive methods of execution. The wording of Art. 539 of the CC has a dispositive character, which gives the debtor the right to choose in an alternative obligation and not provided by any other rule that encourages the debtor to make such a choice. Therefore, we consider that Art. 539 of the Civil Code of Ukraine requires editorial clarification by adding part 3 of the following content: "an alternative obligation becomes ordinary (not alternative) after the choice by the party who has right for it", and also part 4 of the following content: "if the party to whom the right of choice is exercised has not made the choice before the due date of performance of the obligation, or other term specified in the contract or law, the right of choice of performance shall pass to the other party".

Not provided by the CC of Ukraine the consequences of the inability to fulfill an alternative obligation, the ways of solving this issue are researched by the author separately ${ }^{4}$. Optional obligations are also highlighted in the literature. But in modern civil science, the existence of optional obligations raises doubts as to the appropriateness of their existence ${ }^{5}$.

The content of the obligation legal relationship constitutes the right of claim of the creditor and the debt of the debtor.

The content of the right of claim of the creditor consists of the ability of its owner (creditor) to demand from the obliged person (debtor) to perform or refrain from carrying out a certain action (actions), in the case of performing a duty - to obtain and assign the results of such execution.

We consider that a breach of obligation creates a new obligation, a completely different type - a security obligation that aims to restore the rights of the victim. The right to defense that arose from the exercise of a regulatory relationship is an independent subjective right and is not an integral part or particular stage of the development of regulatory subjective law. It is necessary to distinguish between actions as the actual object of the obligation and actions constituting the fulfillment of a new obligation, which arose as a result of violation of the creditor's right under the former obligation. However, the term "former obligation" is not entirely accurate, as these obligations (breached and guarded) may exist in parallel. Although a liability arising from a breach of the creditor's liability under the obligation is a new obligation, it should not be regarded as an innovation, i.e. the grounds for termination of the original obligation.

\footnotetext{
${ }^{4}$ Голубєва Н.Ю. Поняття альтернативних зобов'язань за цивільним законодавствам України та шляхи удосконалення їх правового регулювання. Часопис ицивілістики. 2015. № 18. C. 3-13.

5 Докладніше у праці: Голубєва Н.Ю. Ефективність застосування факультативних зобов’язань у цивільних відносинах. Часопис ичивілістики. 2016. № 20. С. 221-225.
} 
Another component of the content of the obligatory legal relationship is the debt of the debtor. The essence of the duty is to perform or retain a specific action in the interests of the subjective person.

In civilistic doctrine, as a rule, the terms "debt" and "obligation" are used in the same way, which is true, but it is impossible to equate the concept of "debt", "duty" with the concept of "obligation".

In the CC, the term "debt" is used in the following statements, which can be interpreted as: first, "duty": "to repay debts - means to perform duties (Part 3, Art. 44, Art. 366 of the CC); "To pay debts" means to fulfill a duty (Part 4 of Art. 124 of the CC); "Debt forgiveness" means discharge from duty (s) (Art. 605 of the CC); in Part 2 of Art. 191 of the CC, the term "debt" is used in one logical line, with the term "right of claim", and therefore means - duty; "Replacement of debt" means "replacement of the obligation of a prior obligation to a debt obligation", since in a debt obligation - only one party has obligations - it is the debtor (in respect of a specific obligation) and in a prior obligation, even if the prior obligation is unilateral, it is a duty, because if the previous contract was fully responsible for the subject matter of the loan agreement, it could not have been a different contract but was a hidden loan agreement (Part 1 of Art. 1053 of the CC);"transfer of debt" means the replacement of the debtor, the transfer of duties of one person to another (Art. 520 of the CC);"deduction of the share of the testator's debts attributable to this property" means the reduction of the hereditary mass due to the performance of the obligations of the testator in his obligations (art. 1238 of the CC); "Debtor's debts" - obligations under obligations (art. 1281 of the CC) "recognition of ..debt or other obligation" - means recognition of a liability in a monetary obligation or other obligation (art. 264 of the CC); secondly, "obligations": "to answer for debts" - means to answer for obligations (Part 2 of Art. 124, Art. 1043 of the CC); "Personal debts of a company member" - means the personal obligations of a company member, as opposed to the obligations of the company (Part 1 of Art. 149 of the CC of Ukraine);third, a certain amount of cash: "amount of debt" - means a certain amount of cash, not a monetary obligation as a whole or a debt of the debtor (art. 625, 966, 1084 of the CC); "Principal payment" means the payment of a certain amount of money (art. 554 of the $\mathrm{CC}$ ), since the term "payment" is usually associated with the subject of monetary obligations; "making a deptin a notary's deposit" (art. 537 of the CC) - deposit of money or securities in a notary's deposit; fourth, a debt document (art. 18, 545 of the CC).

In the framework of the rules on the surety contract, the term debt is used in different meanings: 1) "payment of principal dept" means a certain amount of money, securities, etc. (Art. 554 of the CC); 2) "to admit a debt" - to admit a debt, to admit a duty in any obligation, and not only for a monetary 
obligation (Art. 555 of the CC); 3) "transfer of debt to another person" (Art.559 of the CC) - transfer of duty of the debtor to another person.

The use of the term "debt" in a binding manner generally makes it difficult to apply the rules of law, even when the same terms are applied in different fields of law. A possible way out of this situation is to change the word "debt" in the CC to other terms: liabilities, monetary obligations, amount of money, obligation - within the meaning of a particular article of the CC.

The obligations of the debtor do not have homogeneous nature: they may include basic and additional responsibilities. Basic obligations actually form a binding legal relationship as a separate kind, they form the nature of the relevant obligation and are crucial for the classification of different types of obligations (to transfer goods, perform and transfer work, provide a service, etc.).

Additional responsibilities provide the order in which basic responsibilities are fulfilled. By analyzing the additional responsibilities in the content of the obligation, it can be stated that they are characterized by the fact that they do not have counter obligations. Thus, if the transfer of the work and its acceptance have the nature of counter-synagmatic duties, the information obligation does not imply the counter-obligation of the other party. The other party has a correspondent right to request relevant information, but there is no counter-obligation.

As a rule, talking about the content of obligations in Ukrainian civil science, the focus is on the obligations of the debtor, who correspond to the rights of the claim of the creditor. But in this category of obligations the obligations of the debtor are not exhausted, the security duties and the obligations of the debtor must be researched separately.

\section{CONCLUSIONS}

Thus, there are several types of responsibilities in obligatory legal relationship. First, the obligations to provide (debt) - are the basic obligations in the obligation to which the creditor's rights correspond. Providing, as a general rule, creates certain benefits for the creditor. Second, security obligations that are designed to protect the interests of the parties in obligation that is not directly related to the provision. Third, creditor obligations.

Based on the research of features, elements of the obligation and the analysis of the legislative definition of "obligation" it is proposed to clarify it as follows: "1. An obligation is a civil legal relationship in which one party (debtor) is obliged to perform certain actions (transfer of property, perform work, provide service, pay money, etc.) of property or non-property nature or to abstain from the other party (creditor) certain actions, and the creditor has the right to demand from the debtor the performance of his/her duty, or both parties act as creditors and debtors against each other". 
The actions of a debtor of a non-material nature must be expressly provided for in the contract or law, and shall comply with the requirements of this Code, other acts of civil law, the principles of reasonableness and justice.

General provisions on obligations may apply to restitutionary, corporate civil legal relations, unless otherwise specified by the Civil Code of Ukraine and other laws and do not follow from the substance of the relevant legal relationship. "

The following definition differs from the existing definition be: a) an indication of the civil legal nature of the relationship; b) an indication of the possibility of the debtor's obligation of property or non-property; c) an indication of the multiplicity of actions as the object of the obligation; d) an indication of the possibility of a two-way binding obligation; e) established criteria for the delimitation of non-property obligations with different kinds of household promises, moral obligations; f) an indication of the possibility of applying to the restitutionary, corporate civil legal relations the rules of obligations, which will emphasize their different legal nature, but the possibility of subsidiary application of the rules to the relevant relations.

Clarification of the possibility of a two-way binding obligation can be done in another way: set out Part 1 of Art. 510 of the Civil Code of Ukraine (which now has the following meaning: "the parties of the obligation are the debtor and the creditor").

Thus, many common law issues give rise to lengthy discussions. For example, the dispute about the objects of legal relations, including obligations, has been going on for decades, different authors put forward different, more often fair, logical and substantiated theories, but it seems that the dispute is being conducted "for the sake of dispute". Today there are so many different views on the legal relationship, its object, subject matter and content that it seems that a single, common position will never be developed.

Our scientific exploration is aimed at developing a general concept of obligation that would correspond the current state of civil science. However, such concept may not be perfect a priori, it cannot solve all the problems accumulated in theory and in practice. Its main purpose - is to stimulate further research in order to improve the general provisions on obligations in Ukrainian law.

\section{SUMMARY}

The section aims to formulate basic provisions on obligations on a single methodological basis, to create a scientific concept, which would lead to the improvement of legislation on obligations. It is noted that only the development of a general theory on obligations in the legislative order, the establishment of abstract bases of the obligation law, allowed to depart from legal formalism, casuistry, the regulation of specific relationships to effectively regulate new obligations that appear with the development of society. 
General provisions on obligations are the basis that must be met by every obligation, unless otherwise stated in the law, contract, and their elaboration is a challenge for the legislator.

The historical approach is used in the section to investigate specifics of obligation from their appearance in Roman law. It is revealed that the main tendencies in the development of the obligation law are: unity, differentiation and unification of special legislation, prevailing development of contract law, differentiation of contract law by economic activity, strengthening globalization.

Based on the research of features, elements of the obligation and the analysis of the legislative definition of "obligation" the conclusion on the new approach to the definition of obligation is drawn. It is proposed to understand an obligation as a civil legal relationship in which one party (debtor) is obliged to perform certain actions of property or non-property nature or to abstain from the other party (creditor) certain actions, and the creditor has the right to demand from the debtor the performance of his/her duty, or both parties act as creditors and debtors against each other.

On the basis of the analysis of the doctrine and the legislation, changes in the definition of the obligation, its object and its content are proposed.

\section{REFERENCES}

1. Голевинский В.И. О происхождении и делении обязательств. Варшава: Тип. О. Бергера, 1872.310 с.

2. Голубєва Н.Ю. Зобов'язання у цивільному праві України : методологічні засади правового регулювання : монографія. Одеса: Фенікс, 2013. 642 с.

3. Голубєва Н.Ю. Поняття альтернативних зобов'язань за цивільним законодавствам України та шляхи удосконалення їх правового регулювання. Часопис ииивілістики. 2015. № 18. С. 3-13.

4. Голубєва Н.Ю. Ефективність застосування факультативних зобов'язань у цивільних відносинах. Часопис цивілістики. 2016. № 20. C. $221-225$.

5. Харитонов Е. Категория обязательств в римском частном праве. Юридический вестник. 1997. № 1. С. 105-109.

\section{Information about the author: \\ Golubeva N. Yu.,}

Doctor of Law, Professor,

Head of the Department of Civil Procedure, Professor of the Department of Civil Law National University "Odesa Law Academy"

Fontan road 23, Odesa, Ukraine

ORCID ID: https://orcid.org/0000-0002-3071-4990 